\section{Employment and Remuneration Trends in Polish Hard Coal Mines in the Context of the Relations Between Boards and Trade Unions}

\author{
Izabela Jonek-Kowalska \\ Silesian University of Technology, Faculty of Organization and Management \\ ul. Roosevelta 26, 41-800 Zabrze, Poland \\ izabela.jonek-kowalska@polsl.pl
}

Employment and Remuneration

Trends in Polish Hard Coal Mines in the Context of the Relations

Between Boards and Trade Unions

\begin{abstract}
Purpose - The main purpose of the article is to identify the economic and financial consequences of a lack of cooperation between trade unions and the board in the Polish hard coal mining industry. Design/methodology/approach - The data from 24 hard coal mines were used in research to determine the level of remuneration and total productivity as well as connections between their values in the examined mining enterprises in the years 2005-2012. The Author formulated three research questions: (Q1) Is the increase in employee remuneration in the examined mining enterprises justified by the increase in workforce productivity? (Q2) Does the decrease in employment and excavation in the examined mining enterprises result in remuneration and total cost reduction? (Q3) What is the role of trade unions in determining efficiency in the examined enterprises?

Findings - In the examined mining enterprises, trade unions mainly satisfy pay demands of employees as well as members of the board of trade unions in complete isolation from the current market situation and financial results of the examined enterprises.

Research limitations/implication - Research results concern not only state-owned Polish mining enterprises but may also provide valuable information about the consequences of excessive privileges of trade unions for other industries.

Practical implications - The results should help the union representatives to understand the role of economic priorities in surviving the mining industry in Poland. Research results and conclusions may be used in negotiations with trade unions and in shaping relations between trade unions and the board.

Social implications - Research results should also be helpful in understanding the economic consequences of pay demands and absolute protection of workplaces by social stakeholders of mining enterprises. They could help in shaping attitudes of trade unionists in the process of restructuring negotiations.

Originality/value - Originality of the research undertaken is connected with a microeconomic view of the examined mining enterprises and treating them as groups of 24 hard coal mines. An important aspect of the considerations conducted is also to present the role of trade unions in shaping remuneration and financial results of the examined mining enterprises.

Keywords - hard coal mining industry in Poland, trade unions, mining enterprise management, productivity and remuneration in hard coal mining in Poland.
\end{abstract}

Paper type - Research article.

\section{Psynargía}

International Journal of Synergy and Research Vol. 3, 2014 p. $27-43$ 
IJSR 3

\section{Introduction}

Hard coal mining in Poland is an industry of strategic significance to energy security. It also employs over one hundred thousand residents of the Upper-Silesian Coal Basin. Nevertheless, its survival is not guaranteed in a free-market economy, which requires an efficient and effective activity proven by profits and not obstructing the rules of free competition, here meaning a lack of financial support from the state. A situation deteriorating for a few years in the two largest Polish coal producers has inclined the author to analyze the causes of industrial restructuring failure and look to mitigate the effects of the current crisis in Polish hard coal mining industry.

In this article, considerations and research concentrate on assessing the role of trade unions in shaping the economic results of the two largest Polish mining enterprises. Its main purpose is to identify the economic and financial consequences of a lack of cooperation in relations between trade unions and boards in Polish hard coal mining. To this end, the article was divided into three substantial parts concluded by a summary. The first contains a literature review referring to the evolution and role of trade unions in shaping of social-economic relations with a special inclusion of trade unions functioning in hard coal mining industry in Poland and in the world. The second part presents the research methodology. The third part consists of results and assessment of consequences of the cooperation of trade unions with the board for the current economic and financial situation of the examined mining enterprises. In the summary, apart from general research results there are also the conditions necessary for improvement of mining trade union relations with the board, what in the present situation is the only chance for the survival of Polish hard coal mining.

\section{Literature review}

The role of trade unions in the enterprise and in the economy evolved together with socioeconomic development. Originally, their main function was to protect the rights of employees, especially to work in healthy and safe conditions. In time, they came to support employees in the struggle for fair remuneration and additional financial and social employee benefits (Donado and Wälde, 2012). Furthermore, one cannot forget their positive influence on the creation and development of social and welfare security as well as insurance systems.

Nowadays, in developed economies, trade unions, apart from the aforementioned traditional functions, extend the range of their operations by participating in social movements to support local communities and protect the environment, treating such efforts as a natural extension of employee protection. A progressing globalization and internationalization of labor markets requires consideration of social and cultural differences as well as protection of employee rights in less developed regions (Kelemen, 2006; Wills, 2001; Munck, 2000).

Reliable and ethical performance of the tasks of trade unions not only guarantees employee rights but also favors effective and efficient operations of the enterprises in which they work. In such case, the partnership model of cooperation between the trade unions and employers is realized, favoring synergy of this cooperation. However, the 
placement of trade unions on the line between employees and managers may lead to negative synergy if trade unions will take a demanding attitude and the spectrum of their demands will be restricted to pay demands.

Nowadays, trade unions more often campaign for such equity, starting conflicts among the employees of particular enterprises. This is especially visible in the internationalization of enterprises' operations and their expansion in less developed countries. Their affiliation with trade unions, particularly with union authorities, is a source of additional employee benefits, which makes the trade unionists particularly privileged employees. Among those benefits, the following are mentioned most often: higher remuneration, lower probability of losing a job, access to cheaper training and legal advice and increase of social utility thanks to membership in an organization with a strong influence on the working environment (Goerke and Pannenberg, 2011).

Presently, the research on trade unions are conducted in a several different dimensions. Many publications concern the changing role of union organizations and emphasize the development of union functions which now do not involve only protecting the rights of employees. The need of changes in the union organizations results from globalization and the changes observed in labor markets (Martínez-Iñigo et al., 2012; Pulignano, 2010; Zammit and Rizzo, 2002). Results of conducted research indicate the growing role of trade unions in shaping workers' skills and competences and in promoting an egalitarian transformation of a workplace (Baccaro, 2011; Siebert, 2011; Lee and Cassell, 2011; Sullivan, 1985). They also prove that trade unions possess unique knowledge of how organizations really work and that they are repositories of experience embracing many different situations and stretching over many years. So, the trade unions could be used as knowledgeable participants in workplace innovation (Totterdill and Exton, 2014).

The research results also suggest that unions need to develop a more sophisticated analysis of equal opportunities which fully reflects the differences between the experiences of groups of workers and which challenges the fundamental, structural inequalities within organizations and labor markets (Lindsay et al., 2007).

Some dimensions of trade unions' analysis relate to the feminization of these organizations and its effect on union activism and solidarity (Turner and D'Art, 2003). In the context of unionists' attitudes, much attention is also paid to organizational and managerial aspects of trade unions. The results of these studies show that management is consciously understood and implemented by trade union leaders who take their managerial roles and achieving the goals of the members seriously (Gall and Fiorito, 2012; Dempsey and Brewster, 2009). Modern techniques of organization and management are used by the union leaders in the process of recruiting new members (Turner et al., 2011) and merging other union organizations (Gennard, 2009). However, the level of organizational development of trade union is still connected with workers' incomes. The results of research undertaken in 15 Western Europe countries show that workers with incomes above the median are better organized than workers below the median (Becher and Pontusson, 2011).

A lot of attention in the literature and research is also devoted to trade unions in posttransition economies. The results expose the differences in organization, functioning and density of post-communist trade unions in comparison to trade unions in market
Employment and Remuneration Trends in Polish Hard Coal Mines in the Context of the Relations Between Boards and Trade Unions 
IJSR 3

economies. Additionally, they suggested that each of the individual post-transition countries experienced challenges that were unique to them and which reflected their economic, geographical and social situation (Qingjun, 2010; Thoresen, 2005; Kamen, 2005). Therefore, they should seek to adapt to the new conditions and establish a new model of functioning. In this process they could use the experiences and help from developed countries (Tilborg, 2005).

Many well-developed countries have seen a decrease in the volume of trade unions and the so-called union density, defined as the percentage of members of trade unions among the total number of employees. This reduction in density is a result of the progressing individualization of societies and the technological revolution contributing to the decrease of threats to the working environment, decreasing the need for union protection (Donado and Wälde, 2012; Schnabel and Wagner, 2007; Fenn and Ashby, 2004; Freeman, 1998). However, the activity of trade unions is intensified during economic crises, as confirmed by the nationwide protests in Spain, Greece and France in the years 2008-2009 (Śmietański, 2014).

In Poland, before the economic transformation, over $80 \%$ of all employees belonged to trade unions. Currently union density equals about $15 \%$, which is caused by the circumstances mentioned above as well as a massive emigration after Poland has joined the European Union (Hardy and Fitzgerald, 2010) and the liquidation and transformation of large national enterprises in which trade unions were traditionally functioning (Czarzasty et al., 2014).

In hard coal mining, due to numerous and unique threats to human life and health, trade unions have a special role, ensuring compliance with health and safety regulations (Rakowska and Cichorzewska, 2012; Liu, 2011; Sadler, 2004; Sadler and Thompson, 2001). Such fulfillment of primary and traditional functions of trade unions may also be observed in underdeveloped countries in African, Asian or South American mining regions (Stirling, 2011). However, in these countries, mining is treated as a development drive, which favors corruption and involvement of trade unions in unethical practices to maximize financial profits for international corporations at the ruthless expense of local communities (Smith and Dorward, 2014; Smith et al., 2012).

Nevertheless, in developed countries, trade unions in the mining industry, apart from the traditional functions, also aim to limit the harm of resource exploitation to the local communities as well as to the natural environment. In this way they often become an element of social campaigns conducted by mining enterprises.

In Poland, trade unions have existed since the beginning of the mining industry, mainly fulfilling the traditional functions of unions by helping to maintain healthy and safe working conditions, appropriate remuneration, and numerous pay benefits. Currently in Poland there are over two hundred trade unions functioning in the hard coal mining industry and the level of unionization in the two largest mining enterprises equals $100 \%$. Union density can even exceed $100 \%$ because some employees sign in to several trade unions. The high number and population give trade unions in the mining industry a great bargaining power in the relations with the management and the state owner.

The privileges of the members of the board of trade unions are another stimulus for creating newer employee representations (Trappmann et al., 2014; Gardawski, 2009; 
Gardawski et al., 1999). In Poland, a trade union can be created by ten employees who choose from among themselves a founding committee of between 3 to 7 members. The employees who become members of the board of the union are exempt from the obligation to perform work for the employer. This privilege can be enjoyed by one board member if the trade union has less than 150 members, one employee if the union has 151-500 members, two employees if the union has 501-2000 members and three employees if the union has over 2000 members (Trappmann, 2014). More members of the board are exempt from obligation of work for each additional thousand members of the given trade union. Furthermore, the employer cannot dismiss or change the working conditions of the members of the board without obtaining permission from the board. Also he cannot enter a collective agreement if not all trade unions operating within the enterprise accept the provisions contained therein (Act of 23 May 1991 on trade unions).

\section{Methodology}

The considerations and research are concentrated on the role of trade unions in the economic results of two largest Polish mining enterprises. The main purpose of the article is to identify the economic and financial consequences of poor synergy in relations between trade unions and a board in Polish hard coal mining. The research encompassed the years 2005-2012. It was conducted in the two largest mining enterprises producing power coal, uniting 24 hard coal mines in their structures. In the course of research, the author formulated three research questions:

(Q1) Is the increase in employee remuneration in the examined mining enterprises justified by the increase in workforce productivity?

(Q2) Does the decrease in employment and excavation in the examined mining enterprises result in remuneration and total cost reduction?

(Q3) What is the role of trade unions in determining efficiency in the examined enterprises?

The subsequent research stages, their detailed objectives, and data and ratios used are presented in Figure 1.

The originality of research is connected with a microeconomic view on the examined mining enterprises and treating them as groups of 24 hard coal mines. Such analysis, due to a lack of access to data about the particular mines, is rarely performed and indicates a large economic and financial differentiation of the mines, which has a strong impact on their final results. An important aspect of the research is the role of trade unions in shaping remuneration and financial results of examined mining enterprises.
Employment and Remuneration Trends in Polish Hard Coal Mines in the Context of the Relations Between Boards and Trade Unions 
IJSR 3

Figure 1:

Methodology of research conducted

\section{STAGES}
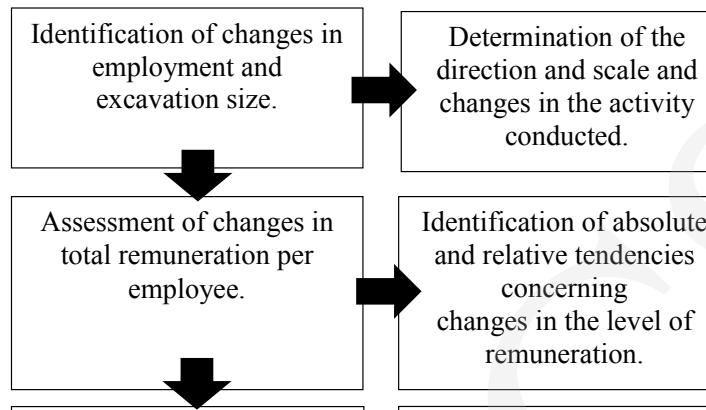

Analysis of relation between remuneration and workforce productivity.

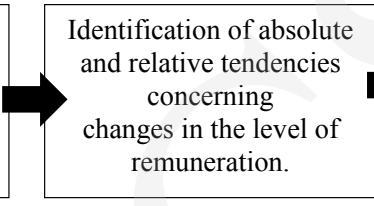

Determination of regular relations between remuneration and workforce productivity.
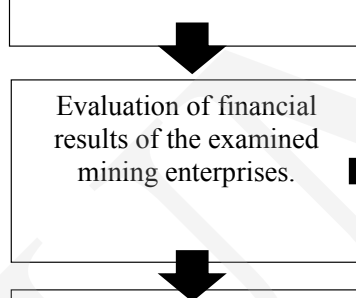

Analysis and assessment of cost of pay of trade unions functioning in the context of changes in employment, remuneration and productivity.
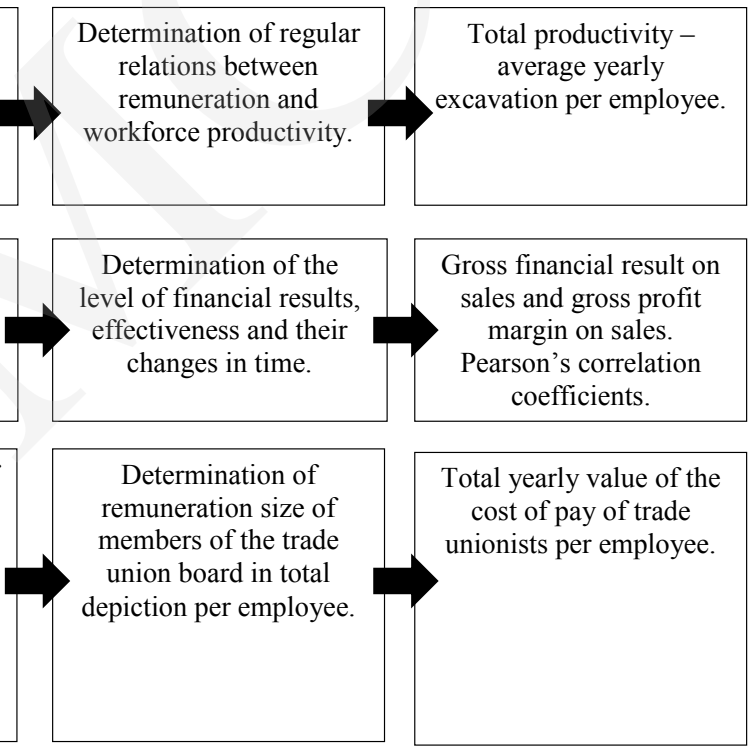

Total yearly value of the cost of pay of trade unionists per employee.

Source: Own work.

\section{Results}

\section{Remuneration versus productivity and financial results}

\section{in the examined mining enterprises}

Demand for hard coal decreased in the country and Europe reduced its overall hard coal excavation from 2006-2012. At the end of 2012, the mines comprising the analyzed mining enterprises excavated almost $30 \%$ less hard coal in total than in the year 2006 . The period of two largest falls of excavation encompasses the years 2006-2010 (Figure 2). In the years 2011-2012, the fall of excavation was limited as a result of improvement of the industry economy and rising demand for electricity after the global economic crisis. At that time, these enterprises periodically improved their economic and financial results due to price increase of hard coal on the European and domestic markets.

A systematic decrease of excavation was accompanied by employment reduction. However, the pace of this process was much slower than the pace of excavation fall 
until 2010 and in 2012 (Figure 2). In 2009, during the post-crisis revival, employment even rose due to the temporary increase in demand. Only in 2011 employment did go down faster than excavation. As a result, over the whole analyzed period, employment was reduced by about 16\% in total (Gumiński 2014; Zieliński, 2014a; Zieliński, 2014b; Gumiński 2012).

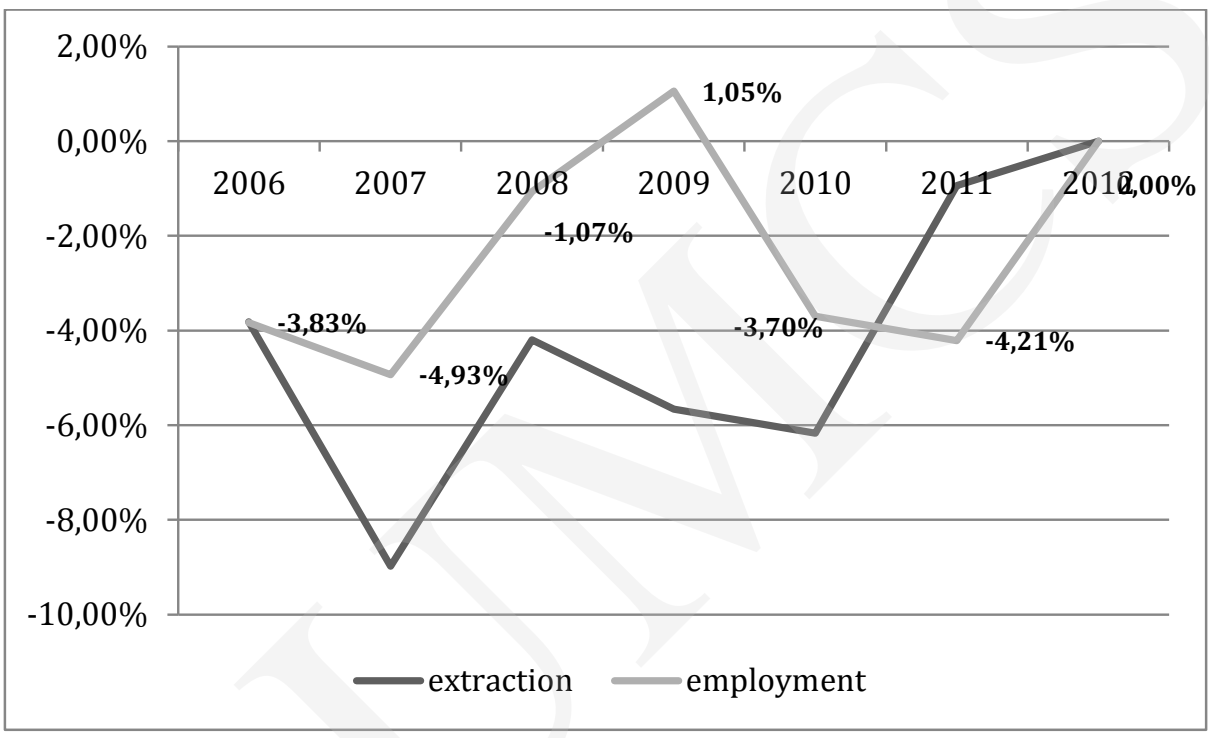

Source: Own work.

Despite a decreasing demand for hard coal caused by advancing European decarbonization policy and decreasing employment, remuneration systematically rose over time (Figure 3). Within the eight analyzed years, total remuneration increase equaled over $35 \%$. After the inclusion of changes in employment, the increase of average monthly pay in the particular mines amounted from $38-101 \%$ in the years 2005-2012 (Figure 3) (Turek, 2013a; Turek, 2013b). Most intense growth in remuneration was observed in the years 2008-2009 and 2011-2012. In these periods the situation on the world coal market had periodically improved and the prices of hard coal had risen which positively influenced the financial results of the examined mining enterprises. Unfortunately, cyclical financial surplus was spent almost entirely on increase in wages enforced by mining trade unions. Such decisions prevented the accumulation of financial reserves necessary for survival in times of recession when additionally the trade unions were blocking the flexible adjustment of wages and employment to the deteriorating market situation.

The remuneration increase presented in Figure 2 and Table 2 did not find its reflection in workforce productivity. The average yearly productivity went up in only 5 out of 24 hard coal mines (Table 2, Figure 4); however, this rise equaled from 1-15\%. In the remaining 19 mines a considerable fall of productivity was observed, amounting to from $0.6 \%$ to over $44 \%$.
Employment and Remuneration Trends in Polish Hard Coal Mines in the Context of the Relations Between Boards and Trade Unions

Figoure 2:

Total change of excavation and employment in the examined mining enterprises in the years

2005-2012

(year to year) [\%] 
Pobrane z czasopisma International Journal of Synergy and Research http://ijsr.journals.umcs.pl

Data: 26/04/2023 16:13:28

\section{IJSR}

3

\section{Figure 3:}

Total remuneration in the examined mining enterprises in the years 2005-2012

[in PLN million]
Table 1:

Average monthly remuneration in the years 2005-2012 in the examined hard coal mines [in PLN]

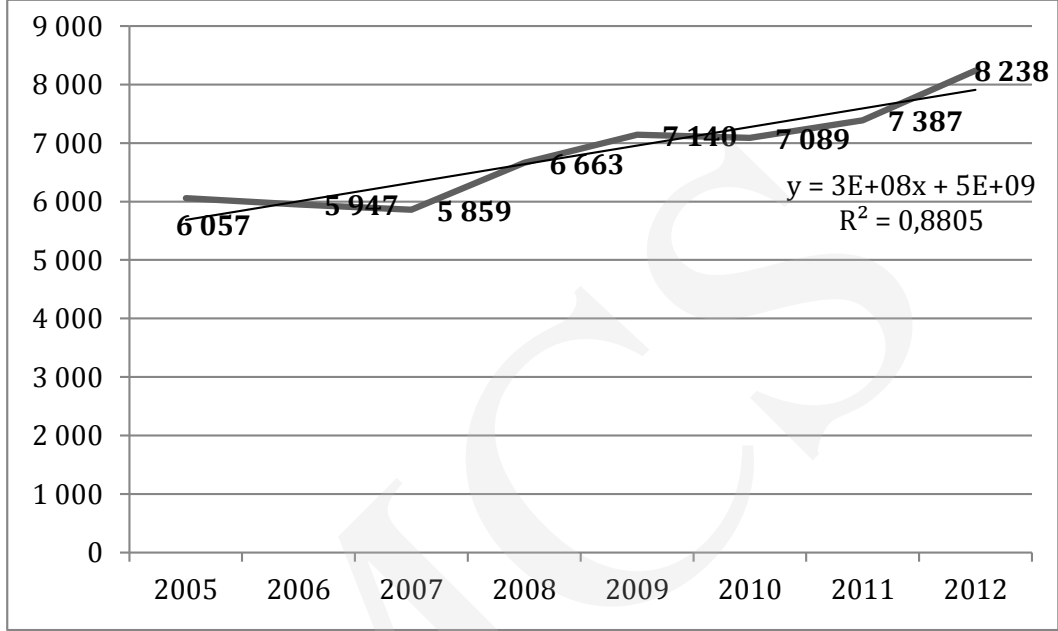

Source: Own work.

\begin{tabular}{|c|c|c|c|c|c|c|c|c|c|}
\hline \multirow{2}{*}{$\begin{array}{l}\text { No. of } \\
\text { mine }\end{array}$} & \multicolumn{8}{|c|}{ Years } & \multirow{2}{*}{$\begin{array}{c}\text { Change } \\
(2012 / 2005)\end{array}$} \\
\hline & 2005 & 2006 & 2007 & 2008 & 2009 & 2010 & 2011 & 2012 & \\
\hline 1 & 5497 & 5642 & 5722 & 6730 & 6909 & 7520 & 8003 & 8003 & $46 \%$ \\
\hline 2 & 5363 & 5465 & 5635 & 6495 & 6932 & 7716 & 7619 & 9074 & $69 \%$ \\
\hline 3 & 5419 & 5443 & 5663 & 6651 & 7089 & 7308 & 7910 & 10887 & $101 \%$ \\
\hline 4 & 5381 & 5519 & 5775 & 6597 & 7052 & 7205 & 8111 & 9230 & $72 \%$ \\
\hline 5 & 5364 & 5393 & 5713 & 6589 & 7067 & 7262 & 8194 & 9326 & $74 \%$ \\
\hline 6 & 5454 & 5393 & 5743 & 6667 & 7111 & 7471 & \multicolumn{2}{|c|}{ Merged with K4. } & $37 \%$ \\
\hline 7 & 5471 & 5747 & 5875 & 6735 & 7163 & 7358 & 8215 & 9471 & $73 \%$ \\
\hline 8 & 5621 & 5661 & 5800 & 6574 & 7131 & 7315 & 8413 & 9345 & $66 \%$ \\
\hline 9 & 5525 & 5702 & 5764 & 6682 & 7190 & 7108 & 8113 & 9398 & $70 \%$ \\
\hline 10 & 5195 & 5384 & 5681 & 6557 & 7118 & 7646 & 7200 & 8945 & $72 \%$ \\
\hline 11 & 5182 & 5527 & 5773 & 6623 & 6955 & 7784 & 8109 & 10009 & $93 \%$ \\
\hline 12 & 5101 & 5248 & \multicolumn{6}{|c|}{ Merged with K 10.} & $3 \%$ \\
\hline 13 & 5154 & 5452 & 5675 & 6561 & 7022 & 7213 & 7951 & 9100 & $77 \%$ \\
\hline 14 & 5475 & 5513 & 5885 & 6669 & 7157 & 7287 & 8313 & 8835 & $61 \%$ \\
\hline 15 & 5855 & 5676 & 5867 & 6752 & 7287 & 7237 & 8512 & 8965 & $53 \%$ \\
\hline 16 & 5599 & 5604 & 5903 & 6767 & 7254 & 6930 & 8554 & 9385 & $68 \%$ \\
\hline 17 & 5398 & 5579 & 5788 & 6531 & 7371 & 7337 & 8472 & 8254 & $53 \%$ \\
\hline 18 & 5785 & 5868 & 5954 & 6857 & 7019 & \multicolumn{3}{|c|}{ Merged with K 23.} & $21 \%$ \\
\hline 19 & 5738 & 5777 & 6005 & 6928 & 7363 & 7384 & 7481 & 8232 & $43 \%$ \\
\hline 20 & 5685 & 5908 & \multicolumn{6}{|c|}{ Merged with K 19.} & $4 \%$ \\
\hline 21 & 5889 & 5898 & 6012 & 6916 & 6954 & 7357 & 7794 & 8464 & $44 \%$ \\
\hline 22 & 5748 & 5894 & 6084 & 6881 & 7043 & 7447 & 7520 & 8395 & $46 \%$ \\
\hline 23 & 5815 & 5951 & 6065 & 6977 & 6638 & 7016 & 7403 & 8002 & $38 \%$ \\
\hline 24 & 5320 & 5517 & 5658 & 6647 & 6885 & 7050 & 7042 & 7579 & $42 \%$ \\
\hline
\end{tabular}

Source: Internal data from the examined hard coal mines. 
Pobrane z czasopisma International Journal of Synergy and Research http://ijsr.journals.umcs.pl

Data: 26/04/2023 16:13:28

\begin{tabular}{rrrrrrrrrr}
\hline $\begin{array}{r}\text { No. of } \\
\text { mine }\end{array}$ & \multicolumn{1}{c}{ 2005 } & \multicolumn{1}{c}{ 2006 } & \multicolumn{1}{c}{ Years } & \multicolumn{1}{c}{2008} & \multicolumn{1}{c}{2009} & \multicolumn{1}{c}{2010} & \multicolumn{1}{c}{2011} & \multicolumn{1}{c}{2012} & $(2012 / 2005)$ \\
\hline 1 & 528.44 & 564.47 & 494.72 & 589.38 & 502.14 & 562.90 & 525.28 & 525.28 & $-0.60 \%$ \\
2 & 558.80 & 548.86 & 473.61 & 410.40 & 386.48 & 404.89 & 342.56 & 375.05 & $-32.88 \%$ \\
3 & 632.61 & 743.98 & 752.33 & 793.98 & 680.22 & 726.92 & 747.25 & 669.27 & $5.79 \%$ \\
4 & 736.17 & 707.30 & 685.40 & 704.76 & 630.90 & 655.76 & 610.90 & 507.74 & $-31.03 \%$ \\
5 & 661.45 & 673.09 & 716.11 & 672.27 & 564.55 & 533.70 & 514.00 & 573.23 & $-13.34 \%$ \\
6 & 715.13 & 648.60 & 570.30 & 481.87 & 541.09 & 480.51 & 0.00 & 0.00 & $-32.81 \%$ \\
7 & 532.26 & 542.72 & 438.72 & 410.93 & 367.85 & 365.19 & 446.67 & 393.49 & $-26.07 \%$ \\
8 & 563.48 & 541.86 & 585.20 & 541.35 & 561.08 & 574.93 & 556.77 & 570.47 & $1.24 \%$ \\
9 & 698.44 & 685.88 & 703.61 & 772.77 & 652.52 & 651.38 & 657.14 & 668.88 & $-4.23 \%$ \\
10 & 606.23 & 576.71 & 444.51 & 390.20 & 374.33 & 300.08 & 367.72 & 434.77 & $-28.28 \%$ \\
11 & 469.95 & 632.47 & 546.01 & 635.98 & 512.16 & 459.71 & 478.60 & 455.81 & $-3.01 \%$ \\
12 & 565.92 & 467.59 & 0.00 & 0.00 & 0.00 & 0.00 & 0.00 & 0.00 & $-17.38 \%$ \\
13 & 587.01 & 602.50 & 705.96 & 582.79 & 671.13 & 489.70 & 492.70 & 473.82 & $-19.28 \%$ \\
14 & 658.98 & 630.18 & 640.82 & 645.17 & 596.93 & 583.67 & 580.73 & 563.92 & $-14.43 \%$ \\
15 & 774.63 & 772.72 & 778.40 & 624.74 & 659.57 & 677.94 & 627.20 & 642.61 & $-17.04 \%$ \\
16 & 696.08 & 751.79 & 762.96 & 835.02 & 748.87 & 773.87 & 798.49 & 798.36 & $14.69 \%$ \\
17 & 552.88 & 505.66 & 463.31 & 496.13 & 429.52 & 445.99 & 442.11 & 462.44 & $-16.36 \%$ \\
18 & 631.75 & 534.85 & 533.77 & 556.59 & 479.39 & 0.00 & 0.00 & 0.00 & $-24.12 \%$ \\
19 & 537.57 & 505.39 & 562.35 & 490.38 & 503.51 & 536.10 & 600.88 & 611.34 & $13.72 \%$ \\
20 & 688.74 & 700.17 & 0.00 & 0.00 & 0.00 & 0.00 & 0.00 & 0.00 & $1.66 \%$ \\
21 & 521.79 & 660.85 & 602.95 & 593.95 & 582.91 & 595.00 & 603.79 & 579.04 & $10.97 \%$ \\
22 & 638.39 & 697.39 & 650.62 & 644.88 & 562.38 & 509.78 & 542.88 & 457.87 & $-28.28 \%$ \\
23 & 818.43 & 785.43 & 685.23 & 604.39 & 562.43 & 472.77 & 508.65 & 454.12 & $-44.51 \%$ \\
24 & 399.66 & 381.86 & 398.65 & 358.61 & 318.66 & 280.93 & 319.38 & 285.11 & $-28.66 \%$ \\
\hline
\end{tabular}

Employment and Remuneration Trends in Polish Hard Coal Mines in the Context of the Relations Between Boards and Trade Unions

Source: Internal data from the examined hard coal mines.

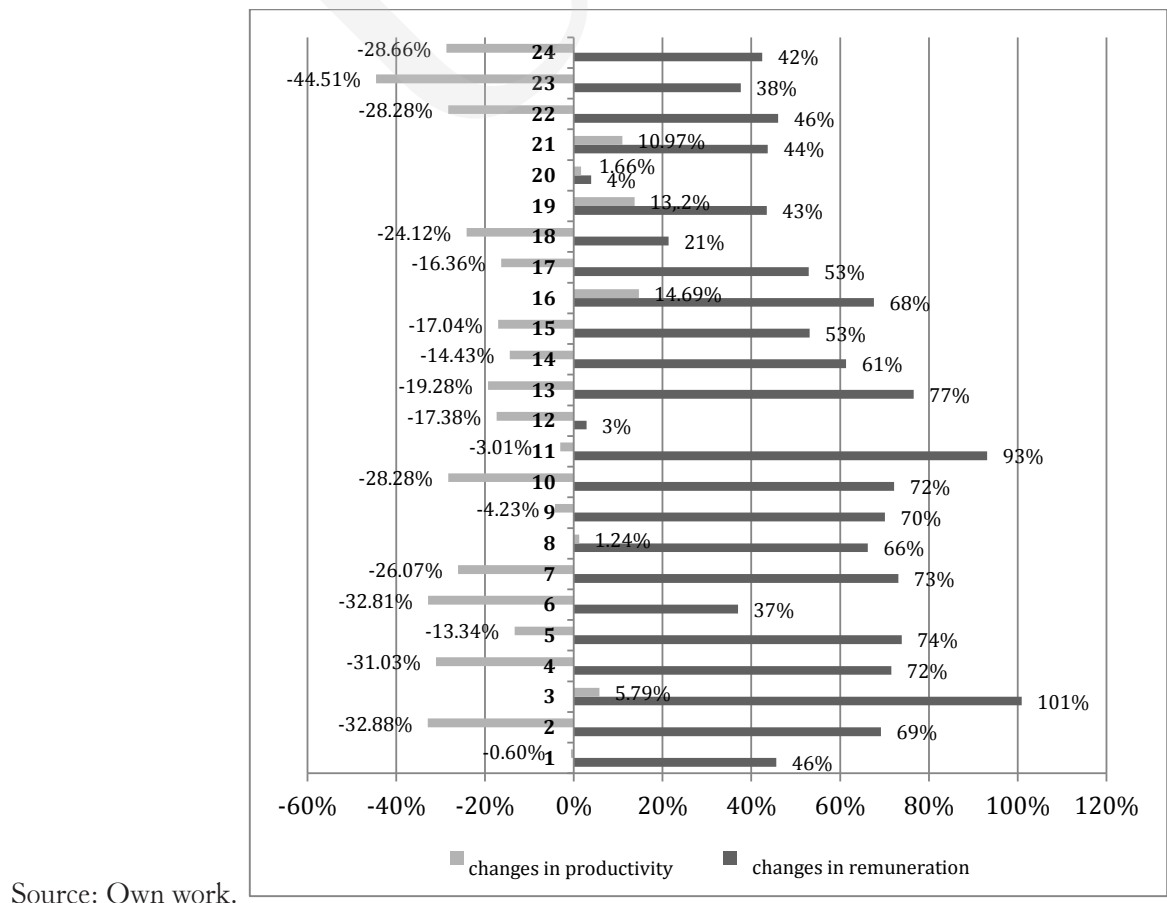

Figure 4: Changes in total productivity and remuneration in the examined hard coal mines in the years 2005-2012 (year 2005 compared to 2012) [\%] 


\section{IJSR}

3

Table 3:

Gross result on sales and gross margin on sales in the examined mining enterprises in the years 2005-2012
Such a significant increase in remuneration, with a lack of economic and productivity-related justification and over $50 \%$ of share of remuneration in the cost of production, results in a considerable deterioration of financial results (Pastuszak et al. 2012, Sitko-Lutek et al., 2012) of the examined mining enterprises (Table 3).

\begin{tabular}{lcccccccc}
\hline Specification & 2005 & 2006 & 2007 & 2008 & 2009 & 2010 & 2011 & 2012 \\
\hline $\begin{array}{l}\text { Gross result } \\
\text { on sales }\end{array}$ & 474643325 & 52596111 & -408405170 & 399944170 & 227968863 & -494063575 & 498473944 & -371108145 \\
$\begin{array}{l}\text { Gross margin } \\
\text { on sales }\end{array}$ & $3.90 \%$ & $0.45 \%$ & $-3.64 \%$ & $2.92 \%$ & $1.53 \%$ & $-3.61 \%$ & $3.21 \%$ & $-2.38 \%$ \\
\hline
\end{tabular}

Source: Own work.

Gross margin obtained by the examined enterprises is very low in the whole examined period and indicates low return on mining production. The worst financial results were obtained in the years 2007, 2010, and 2012. These periods appear directly after the years of good economic situation and rise of hard coal prices on the European and global market. The years 2010 and 2012 were also the years after the largest remuneration increases. These were mostly connected with trade unions' pressure to spend the positive financial result achieved during economic improvement on pay raises not justified by productivity. Acceptance of such demands led in the subsequent years to a significant increase in costs of production, along with a decrease in hard coal prices, which irreversibly sank the analyzed enterprises' financial results.

The lack of economic justification for the changes in efficiency is also confirmed by relationship between excavation, employment and remuneration and total costs in the examined hard coal mines (Table 4).

There were positive, strong and statistically significant relationships between employment and excavation in 11 hard coal mines which means that reduction in excavation caused reduction in employment. However, the reduction in excavation was not reflected in decrease in remuneration and total costs because in most of the examined hard coal mines Pearson's correlation coefficients between these parameters were below zero. The reduction in employment did not cause the reduction in total costs and remuneration either. There were only 3 coal mines with statistically significant and positive Pearson's correlation coefficients between employment and total costs and between employment and remuneration (No. 4, No. 19 and No. 23).

\section{Remuneration demands of trade unions}

In the analyzed period also the remuneration of trade unionists increased by over $31 \%$ from over PLN 23 million in the year 2005 to over PLN 30 million in 2012 (Figure 5). Taking employment reduction into account occurring in this period, the level of remuneration of trade unionists increased a lot per employee (Table 5).

Only in four mines did the average cost of paying trade unionists per employee decrease. In the remaining 20 , a rise of this ratio may be observed, even by over $300 \%$. 
Pobrane z czasopisma International Journal of Synergy and Research http://ijsr.journals.umcs.pl

Data: 26/04/2023 16:13:28

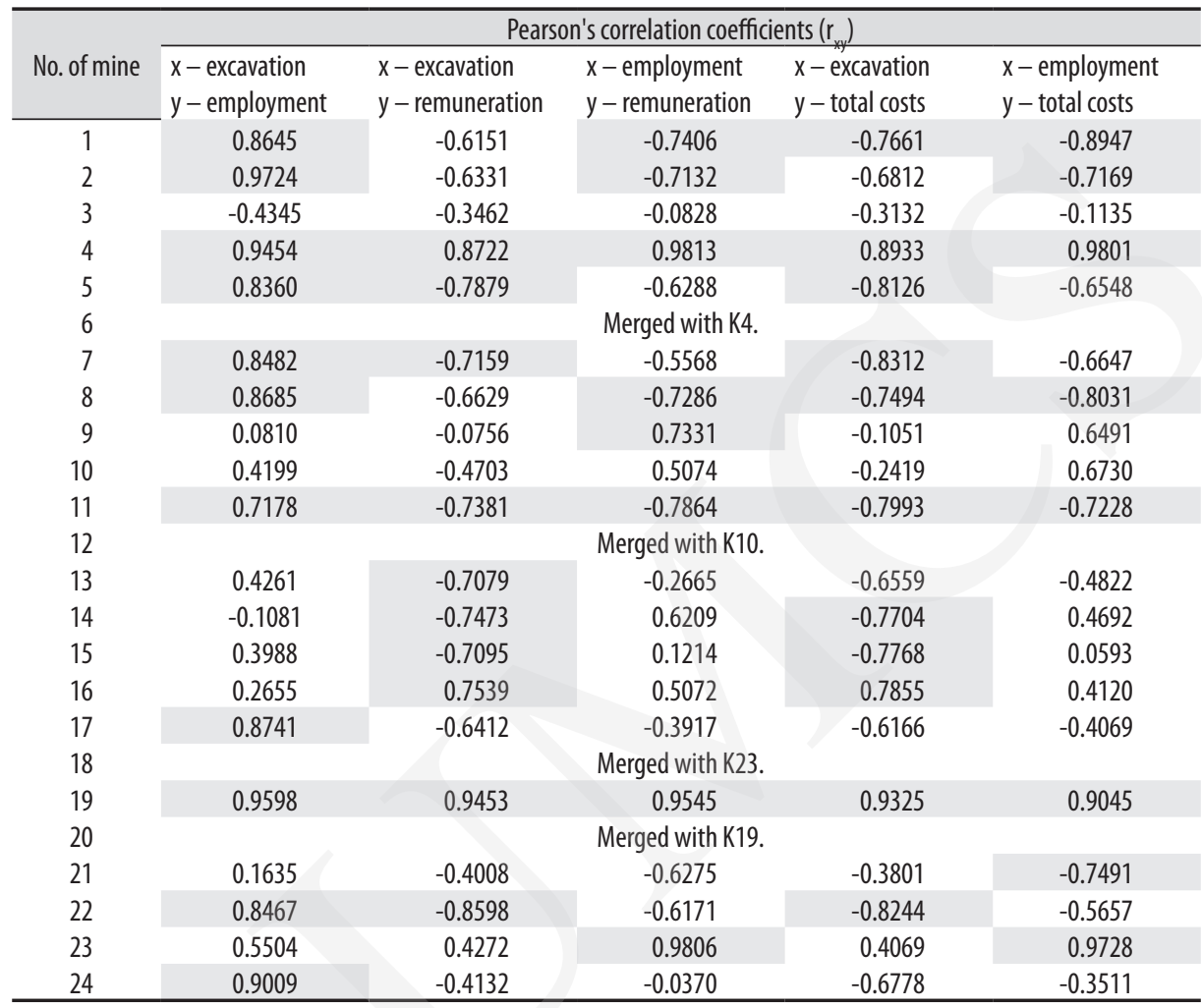

Employment and Remuneration Trends in Polish Hard Coal Mines in the Context of the Relations Between Boards and Trade Unions

- level of significance $p<0.05$

Source: Own work.

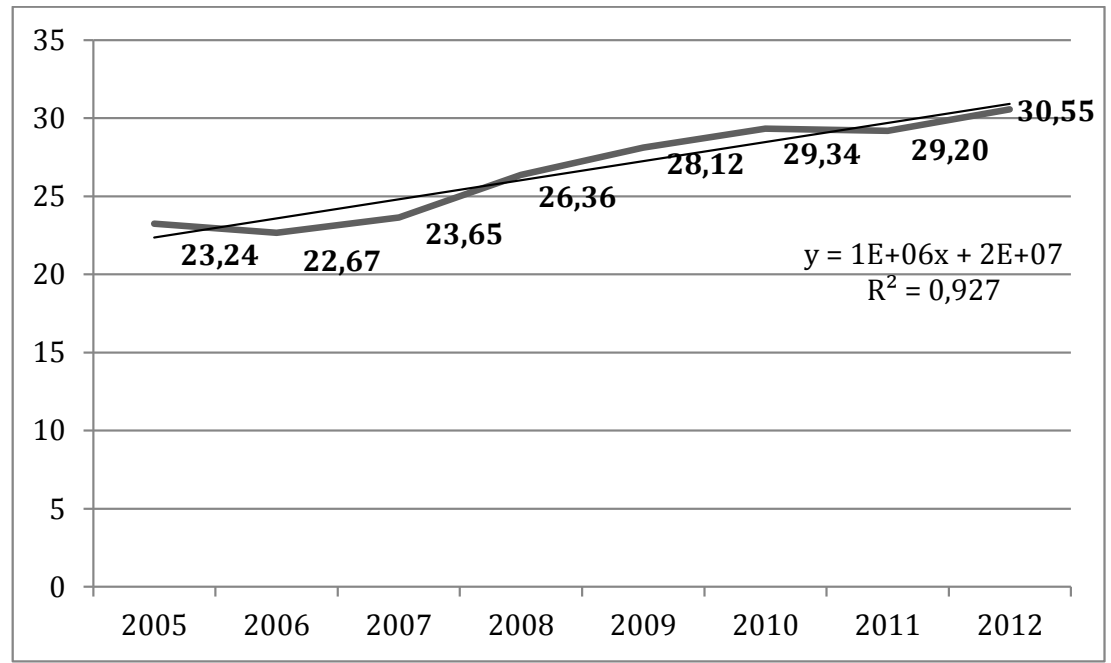

Table 4:

Pearson's correlation coefficients (rxy) between excavation, employment, remuneration and total costs in examined hard coal mines in the years 2005-2012

Figure 5:

Remuneration of employees delegated to work in trade unions in the years 2005-2012 [in million PLN]

Source: Own work based on internal data from the examined hard coal mines 


\section{IJSR}

3
Table 5:

Average cost of pay

of trade unionists per

employee in the years

2005-2012 in the

examined hard coal

mines [PLN/person]

\begin{tabular}{rllrrrrrrr}
\hline $\begin{array}{r}\text { No. of } \\
\text { mine }\end{array}$ & \multicolumn{1}{c}{ 2005 } & \multicolumn{1}{c}{ Years } & \multicolumn{1}{c}{2007} & \multicolumn{1}{c}{2008} & \multicolumn{1}{c}{2009} & \multicolumn{1}{c}{2010} & \multicolumn{1}{c}{2011} & \multicolumn{1}{c}{2012} & $(2012 / 2005)$ \\
\hline 1 & 294.70 & 370.76 & 461.47 & 547.59 & 564.01 & 643.12 & 662.52 & 662.52 & $124.81 \%$ \\
2 & 165.39 & 155.09 & 173.94 & 208.66 & 253.90 & 256.03 & 354.97 & 395.13 & $138.90 \%$ \\
3 & 289.96 & 222.72 & 266.30 & 359.87 & 367.70 & 359.14 & 413.03 & 426.25 & $47.00 \%$ \\
4 & 206.37 & 301.35 & 319.86 & 343.44 & 409.77 & 444.67 & 480.88 & 486.95 & $135.96 \%$ \\
5 & 264.88 & 219.42 & 204.83 & 222.96 & 234.10 & 257.46 & 240.60 & 266.05 & $0.44 \%$ \\
6 & 291.17 & 258.31 & 238.96 & 271.37 & 252.05 & 317.00 & 0.00 & 0.00 & $8.87 \%$ \\
7 & 346.85 & 371.98 & 425.22 & 460.52 & 541.59 & 576.14 & 544.12 & 624.30 & $79.99 \%$ \\
8 & 236.79 & 262.64 & 320.10 & 317.42 & 321.94 & 401.18 & 399.35 & 342.39 & $44.60 \%$ \\
9 & 297.64 & 271.94 & 268.53 & 324.97 & 323.01 & 357.94 & 358.13 & 364.97 & $22.62 \%$ \\
10 & 224.30 & 229.47 & 265.36 & 402.88 & 503.78 & 526.20 & 586.78 & 665.19 & $196.57 \%$ \\
11 & 110.26 & 105.33 & 137.49 & 148.90 & 173.24 & 276.05 & 326.85 & 451.11 & $309.11 \%$ \\
12 & 211.77 & 287.96 & 0.00 & 0.00 & 0.00 & 0.00 & 0.00 & 0.00 & $35.98 \%$ \\
13 & 326.18 & 339.31 & 364.11 & 416.19 & 437.34 & 559.14 & 592.06 & 659.96 & $102.33 \%$ \\
14 & 231.44 & 227.39 & 235.19 & 254.92 & 280.57 & 310.42 & 325.97 & 349.12 & $50.85 \%$ \\
15 & 263.38 & 277.01 & 287.88 & 317.20 & 324.69 & 321.22 & 324.37 & 317.36 & $20.49 \%$ \\
16 & 308.36 & 336.72 & 340.89 & 370.30 & 379.89 & 372.34 & 404.44 & 424.29 & $37.60 \%$ \\
17 & 312.13 & 304.81 & 386.55 & 393.55 & 376.40 & 423.80 & 524.95 & 567.62 & $81.86 \%$ \\
18 & 270.99 & 251.45 & 278.93 & 306.86 & 331.95 & 0.00 & 0.00 & 0.00 & $22.50 \%$ \\
19 & 276.03 & 227.20 & 193.07 & 213.99 & 235.85 & 226.99 & 227.87 & 219.75 & $-20.39 \%$ \\
20 & 169.05 & 169.36 & 0.00 & 0.00 & 0.00 & 0.00 & 0.00 & 0.00 & $0.18 \%$ \\
21 & 191.19 & 154.26 & 153.90 & 205.58 & 166.58 & 229.97 & 151.81 & 178.78 & $-6.49 \%$ \\
22 & 174.20 & 176.41 & 210.99 & 214.89 & 207.67 & 203.32 & 209.80 & 241.58 & $38.68 \%$ \\
23 & 304.34 & 292.82 & 312.88 & 322.42 & 342.48 & 328.08 & 238.21 & 218.46 & $-28.22 \%$ \\
24 & 243.88 & 264.62 & 301.75 & 344.33 & 280.82 & 141.45 & 117.95 & 117.32 & $-51.89 \%$ \\
\hline
\end{tabular}

Source: Internal data from the examined hard coal mines.

\section{Summary}

From the theoretical considerations presented at the beginning of this article, it should be concluded that Polish mining trade unions mostly focused on conducting primary and basic union functions, workplace protection, providing a fair level of remuneration as well as safe and healthy working conditions. Due to continued state ownership in examined mining enterprises, the union functions did not evolve; similarly, the demanding attitude of trade unions did not change, fostered by $100 \%$ union density and a record number of trade unions. In turn, trade unionists achieved bargaining power in such conditions that allows them to obtain all union privileges described in the introduction, regardless of the economics and finances of the examined mining enterprises.

Therefore, from the above, we may conclude that in the examined mining enterprises, trade unions mostly realize the pay demands regarding both employees and the trade union board in a complete isolation from the current market situation and financial results of the examined enterprises. Observation of union negotiations also 
shows that mining trade unions only blame the board of the mining enterprises and the owner of the State Treasury for the current crisis.

Nevertheless, in market deterioration, an enterprise may only influence internal determinants of effectiveness like costs of production. Without comprehending this basic rule and with over $50 \%$ of total costs as pay share, any permanent and significant reduction of cost of production is not possible. Meanwhile, in the examined mining enterprises, despite decreasing excavation and employment, the cost of pay is rising which does not have a rational economic justification in the form of workforce productivity increase.

Trade unions' unwillingness to understand market conditions and adamant negotiation attitudes generate negative synergy in the examined enterprises. A lack of synergy in relations between trade unions and boards precludes the examined mining enterprises from making flexible adjustments of production costs to changing economic conditions, which leaves their financial results in decline. The increase in remuneration, unjustified by productivity, means an increase in unit cost of production and lack of return. In January 2015, one of the enterprises presented in the article faced bankruptcy and liquidated some permanently ineffective coal mines.

In the same period, the EU introduced conditions for the hard coal mining industry in the countries of the European Union. In the period analyzed in the article, hard coal mining was systematically subsidized within the frames of Council Regulation (EC) No. 1407/2002 of 23 July 2002 on state aid to the coal industry. According to this regulation, maintaining domestic energy security was justified by granting state aid for unprofitable hard coal mines (Olkuski, 2011). However, financial support for mining encompassed a wide subject range, which included: aid in closure of unprofitable mines, operating aid, investment aid (Michalak, 2012a; Michalak, 2012b), and aid for inherited extraordinary costs connected with sector restructuring (Paszcza and Białas, 2009).

Nevertheless, these categories of aid were reduced by the European Commission Decision on Aid to facilitate the closure of uncompetitive coal mines (2010/787/UE). According to the Decision, state aid may only be granted for:

$\checkmark$ costs of closure of unprofitable coal mines, also including current production losses, providing that they are finally liquidated on the day of 31 st December 2018,

$\checkmark$ extraordinary costs financed until the end of the year 2026, mostly social (pensions and employee benefits for those who were dismissed) and technical (securing the infrastructure of liquidated mines).

Consequently, the aid for initial investment and aid without time limit were lost, which impeded internal initiatives concerning improvement of sector competitiveness (Białas, 2011).

In face of the legal changes presented above, restructuring of the examined mining enterprises through state aid grants is not possible. The only way to improve their profitability is liquidation of some mines and restructuring of effective mining enterprises from equity or debt capital of the examined enterprises, mostly concerning elaboration of effective motivational systems basing remuneration on rational economic and financial criteria. Nevertheless, without the approval of mining trade unions, such a restructuring will not be possible. A lack of agreement and positive synergy in the relations between trade unions and the boards may lead to liquidation of the whole hard coal mining sector in Poland.
Employment and Remuneration Trends in Polish Hard Coal Mines in the Context of the Relations Between Boards and Trade Unions 
IJSR 3

Presented study indicates the need of improving the process of negotiation between the mining trade unions and the boards of mining enterprises. It also exposes the consequences of unreasonable requirements of branch trade unions concerning rising in wages without taking into account the market situation. The analysis also points to the urgent need to change beliefs and attitudes of mining trade unions. The results should help the union representatives to understand the role of economic priorities in surviving the mining industry in Poland. In this way, shaping attitudes of mining trade unions in order to negotiate the conditions of further restructuring of the mining enterprises could be possible and easier. In the present situation, the successful cooperation between the mining trade unions and boards of the mining enterprises is a key condition in survival of the entire industry.

\section{References}

Act of 23 May 1991 on trade unions, consolidated text, Journal of Laws of 2014, item 167.

Baccaro, L. (2011), “Labor, Globalization and Inequality: Are Trade Unions Still Redistributive?", in: Brady, D. (ed.), Comparing European Workers Part B: Policies and Institutions (Research in the Sociology of Work, Volume 22, Part 2), Emerald Group Publishing Limited, pp. 213-285.

Becher, M. and Pontusson, J. (2011), Whose Interests do Unions Represent? Unionization by Income in Western Europe, in: Brady, D. (ed.), Comparing European Workers Part B: Policies and Institutions (Research in the Sociology of Work, Volume 22 Part 2), Emerald Group Publishing Limited, pp.181-211.

Białas, M., (2011), "Pomoc publiczna dla górnictwa węgla kamiennego w świetle nowej decyzji Rady Unii Europejskiej" (Public aid for coal mining in the light of the new decision of the Council of the European Union), Materiaty XXIII konferencji z cyklu Zagadnienia surowców energetycznych i energii w gospodarce krajowej, Zakopane, pp. 7-28.

Cotton, E. and Royle, T. (2014), "Transnational Organizing: A Case Study of Contract Workers in the Colombian Mining Industry", British Journal of Industrial Relations, No. 12, pp. $705-724$.

Czarzasty, J., Gajewska, K., and Mrozowicki, A. (2014), "Institutions and Strategies: Trends and Obstacles to Recruiting Workers into Trade Unions in Poland", British Journal of Industrial Relations, No. 3, pp. 112-135.

Dempsey, M. and Brewster, Ch. (2009) "On leaving the nunnery: management in trade unions", Employee Relations, Vol. 31, Iss: 4, pp. 347-362.

Donado, A. and Wälde, K. (2012), "How trade unions increase welfare", The Economic Journal, Vol. 122, pp. 990-1009.

Fenn, P. and Ashby, S. (2004), "Workplace risk, establishment size and union density", British Journal of Industrial Relations, Vol. 42, No. 3, pp. 461-80.

Freeman, R. (1998), "Spurts in union growth: defining moments and social processes", in: Bordo, M., Goldin C. and White, E. N. (eds.), The Defining Moment: The Great Depression and the American Economy in the Twentieth Century, Chicago, IL: University of Chicago Press, pp. 265-296.

Gall, G. and Fiorito, J. (2012), "Toward better theory on the relationship between commitment, participation and leadership in unions", Leadership \& Organization Development Journal, Vol. 33, Iss: 8, pp. 715-731.

Gardawski, J. (2009), Dialog spoteczny w Polsce. Teoria, historia, praktyka (Social dialogue in Poland. Theory, history, practice), Warszawa: Ministerstwo Pracy i Polityki Społecznej. Katedra Socjologii Ekonomicznej SGH. 
Gardawski, J., Gąciarz, B., Mokrzyszewski, A and Pańków, W. (1999), Rozpad bastionu. Zwiazki zawodowe w gospodarce prywatyzowanej (The disintegration of the bastion. Trade unions in the privatized economy), Warszawa: Instytut Spraw Publicznych.

Gennard, J. (2009), “Trade union merger strategies: good or bad?”, Employee Relations, Vol. 31, Iss: 2 , pp.116-120.

Goerke, L. and Hillesheim, I. (2013), "Relative consumption, working time, and trade unions", Labour Economics, Vol. 24, pp. 170-179.

Goerke, L. and Pannenberg, M. (2011), "Trade union membership and dismissals", Labour Economics, Vol. 18, pp. 810-821.

Gumiński A., (2012), "Czynniki decydujące o wydajności pracy w wybranych kopalniach węgla kamiennego" ("Factors influencing the labour productivity in selected coal mines"),

Wiadomości Górnicze, no. 10, pp. 562-567.

Gumiński A., (2014), "Wyzwania dla zarządzania zasobami ludzkimi w polskim górnictwie węgla kamiennego" ("The challenges for human resource management in the Polish coal mining industry"), Zeszyty Naukowe Politechniki Ślaskiej, z. 69, pp. 53-62.

Hardy, J. and Fitzgerald, I. (2010), "Negotiating 'solidarity' and internationalism: the response of Polish trade unions to migration", Industrial Relations Journal, Vol. 42, No. 3, pp. $367-381$.

Kamen, V., (2005) "Change and continuity" - the experience of trade unions in the cultural sector of the former Soviet Union", Employee Relations, Vol. 27, Iss: 6, pp. 613-623.

Kelemen, P. (2006), "Modernising colonialism: the British labour movement and Africa", Journal of Imperial and Commonwealth History, Vol. 34, No. 2, pp. 223-244.

Lee, B. and Cassell, C. (2011), "Learning to count: a challenge facing trade unions in their educational role", International Journal of Sociology and Social Policy, Vol. 31, Iss: 5/6, pp. 287-301.

Lindsay, C., Munro, A. and Wise, S. (2007), "Making equalities work? Scottish trade unions' approaches to equal opportunities", Equal Opportunities International, Vol. 26, Iss: 5, pp. 465-481.

Liu, Ch. (2011), "Failures of enterprise-level unionization in China: Implications for coalmine safety and beyond", International Labour Review, Vol. 150, No. 1-2, pp. 163-175.

Martínez-Iñigo, D., Crego, A., Garcia-Dauder, S. and Domínguez-Bilbao, R. (2012), "Organizational culture as a source of change in trade unions", Employee Relations, Vol. 34, Iss: 4, pp. 394-410.

Michalak, A. (2012a), "Identyfikacja źródeł finansowania inwestycji rozwojowych przedsiębiorstw górniczych na tle innych branż kapitałochłonnych" ("Identification of capital sources for development investments in mining enterprises compared to other capital-intensive industries"), in: Zarządzanie finansami. Inwestycje, wycena przedsiębiorstw, zarzadzanie wartościa, Zeszyty Naukowe Uniwersytetu Szczecińskiego $n r$ 639, seria Finanse, rynki finansowe i ubezpieczenia no. 37, Szczecin: Wydawnictwo Uniwersytetu Szczecińskiego, pp. 11-22.

Michalak, A. (2012b), "Wybrane aspekty finansowania inwestycji rozwojowych w branżach kapitałochłonnych" ("Some aspects of financing development investments in capitalintensive industries"), in: Zarządzanie finansami firm - teoria i praktyka, t. 2, Prace Naukowe Uniwersytetu Ekonomicznego we Wrocławiu no. 271, Wrocław: Wydawnictwo Uniwersytetu Ekonomicznego we Wrocławiu, pp. 267-276.

Munck, R. (2000), "Review article: labour and globalisation: results and prospects", Work, Employment and Society, Vol. 14, pp. 385-393.

Olkuski, T. (2011), "Zasoby węgla kamiennego - najpewniejsze źródło energii” ("Resources of hard coal - the most reliable source of energy"), Przeglad Górniczy, Nos. 7-8, pp. 42-45.

Qingjun, W. (2010), "Establishing trade unions within foreign companies in China", Employee Relations, Vol. 32, Iss: 4, pp. 349-363.
Employment and Remuneration Trends in Polish Hard Coal Mines in the Context of the Relations Between Boards and Trade Unions 
IJSR 3

Pastuszak, Z., Huey-Pyng Shyu, S. and Lee, T-R., Anussornnitisarn, P. and Kaewchur O., (2012), "Establishing interrelationships among organisational learning, innovation and performance", International Journal of Innovation and Learning, Vol. 11, Iss. 2, pp. 200-215.

Paszcza, H. and Białas, M., (2009), "Pomoc publiczna dla górnictwa węgla kamiennego - przegląd oraz zagrożenia i perspektywy po 2010 r." ("Public aid for coal mining - an overview of risks and prospects after 2010"), Materiaty XXIII konferencji z cyklu Zagadnienia surowców energetycznych $i$ energii w gospodarce krajowej, Zakopane, pp. 135-156.

Pulignano, V. (2010), "Trade unions and transnational regulation in Europe: developments and limitations", Employee Relations, Vol. 32, Iss: 6, pp. 574-589.

Rakowska, A. and Cichorzewska, A. M., (2012), "Instances of Corporate Social Responsibility in coal mining: an example of chosen Polish mines", Manage. Knowledge Learn. Int. Conf., pp. 393-401.

Sadler, D. (2004), "Trade unions, coalitions and communities: Australia's Construction, Forestry, Mining and Energy Union and the international stakeholder campaign against Rio Tinto", Geoforum, Vol. 35, pp. 35-46.

Sadler, D. and Thompson, J. (2001), "In search of regional industrial culture: the role of labour organisations in old industrial regions", Antipode, Vol. 33, pp. 660-686.

Schnabel, C. and Wagner, J. (2007), "Union density and determinants of union membership in 18 EU countries: evidence from micro data", Industrial Relations Journal, Vol. 38, pp. 5-32.

Siebert, S. (2011), "Are trade unions learning?", Higher Education, Skills and Work-Based Learning, Vol. 1, Iss: 2, pp. 91-94.

Sitko-Lutek, A., Phusavat, K. and Comepa, N. (2012), Interrelationships between intellectual capital and performance: empirical examination, Industrial Management \& Data Systems, Vol. 111, Iss: 6, pp. 810-829.

Smith S., M. and Dorward P., T. (2014), "Nationalised large-scale mining, trade unions and community representation: Perspectives from Northern Madagascar", Resources Policy, Vol. 40, pp. 31-41.

Smith, S. M., Shepherd, D. D. and Dorward, P. T. (2012), "Perspectives on community Representation within the extractive industries transparency initiative: experiences from south-east Madagascar", Resources Policy, Vol. 37, No. 2, pp. 241-250.

Stirling, J. (2011), "Trade unions in a fragile state: the case of Sierra Leone", Industrial Relations Journal, Vol. 42, No. 3, pp. 236-253.

Sullivan, T. (1985), “Trade Unions, Management and Productivity”, Employee Relations, Vol. 7, Iss: 2 , pp. $8-11$.

Śmietański, R. (2014), “Związki zawodowe i ich wpływ na rozwój społeczny i gospodarczy”(“Trade unions and their impact on social and economic development"), Studia Ekonomiczne Uniwersytetu Ekonomicznego w Katowicach, no. 167, pp. 231-239.

Thoresen, F., E. (2005), "Norwegian and Nordic trade union support and solidarity for trade unions in eastern and central Europe", Employee Relations, Vol. 27, Iss: 6, pp. 592-602.

Totterdill, P. and Exton R. (2014) "Trade unions as knowledgeable participants in workplace innovation", Strategic Direction, Vol. 30, Iss: 9, pp. 31-34.

Trappmann, V. (2014), Zwiazki zawodowe w Polsce aktualna sytuacja, struktura organizacyjna, wyzwania (Trade unions in Poland the current situation, organizational structure, challenges), Warszawa: Friedrich Ebert Stiftung.

Trappmann, V., Jasiecki, K. and Przybysz, D. (2014), "Institutions or attitudes? - The role of formal worker representation in labour relations", in: Bluhm, K., Marten, B. and Trappmann, V. (eds.): Business Leaders and New Varieties of Capitalism in Post-Communist Europe, New York: Routledge, pp. 176-204.

Turek M., (2013a), Analiza i ocena kosztów w górnictwie węla kamiennego w Polsce w aspekcie poprawy efektywnosici wydobycia (Analysis and evaluation of the cost in hard coal mining in Poland in terms of improving the efficiency of the excavation), Warszawa: Difin. 
Turek M., (2013b), System zarzadzanie kosztami w kopalni wegla kamiennego w cyklu istnienia wyrobiska wybierkowego (System of cost management in a hard coal mine in the life-cycle of a pit), Warszawa: Difin.

Turner T. and D'Art, D. (2003) “The feminization of Irish trade unions: involvement, solidarity and the relevance of gender", Women in Management Review, Vol. 18, Iss: 5, pp. 228-235.

Turner, T., O'Sullivan, M. and D'Art, D. (2011), "Organising methods and member recruitment in Irish trade unions", Employee Relations, Vol. 33, Iss: 5, pp. 516-531.

van Tilborg, R. (2005), "The Dutch trade unions - and their support activities in central and eastern Europe", Employee Relations, Vol. 27, Iss: 6, pp. 624-634.

Wills, J. (2001), "Community unionism and trade union renewal in the UK: moving beyond the fragments at last?", Transactions of the Institute of British Geographers, Vol. 26, pp. 465483.

Zammit, E., L. and Rizzo, S. (2002), "The perceptions of trade unions by their members: A survey report on trade unions in Malta", Employee Relations, Vol. 24, Iss: 1, pp. 53-68.

Zieliński, M., (2014a), "Potrzeby informacyjne przedsiębiorstwa w okresie restrukturyzacji zatrudnienia" ("Information needs of an enterprise in employment restructuring"), Zeszyty Naukowe Politechniki Śląskiej, z. 68, pp. 141-151.

Zieliński, M., (2014b), "Restrukturyzacja zatrudnienia" (Employment restructuring"), in. Król, M., Warzecha, A. and Zieliński, M., Funkcja personalna $w$ przedsiębiorstwie. Zakres, pomiar realizacji, uwarunkowania, Warszawa: CeDeWu, 2014, pp. 61-79.

\section{Acknowledgments}

The article was financed from statutory research BK 221/ROZ-1/2015.

\section{Biographical notes}

Izabela Jonek-Kowalska obtained a degree of $\mathrm{PhD}$ in economic sciences in 2006 at the Silesian University of Technology where currently she is a lecturer. Her scientific interests focus on the management problems of mining enterprises, restructuring, value and risk in industrial enterprises.
Employment and Remuneration Trends in Polish Hard Coal Mines in the Context of the Relations Between Boards and Trade Unions 